\title{
Study Habits of Highly Effective Medical Students: A Medical Student's Perspective [Letter]
}

\section{Durray Nayab Ali}

The University of Manchester, Faculty of Biology, Medicine and Health, Manchester, UK
Correspondence: Durray Nayab Ali

Email durray.ali@student.Manchester.ac.uk

\section{Dear editor}

I have read the article 'Study Habits of Highly Effective Medical Students' by Bin Abdulrahman et al. ${ }^{1}$ The authors provide an interesting insight into the studying habits of medical students and I want to present my comments on certain aspects of this study.

This article identifies key strategies medical students use in order to study and prepare for exams and briefly identifies the use of group study to practise for OSCEs (Table 3). ${ }^{1}$ However, it is not clearly evident how studying habits differ when preparing for written examinations in comparison to practical examinations. In the UK, we have both written examinations and Objective Structured Clinical Examinations (OSCEs) which assess history taking, physical examination and communication skills. Studies have found that working in small groups that includes role play and interviewing is beneficial in terms of teaching history taking to medical students. ${ }^{2}$ Furthermore, it is a feasible suggestion to make that developing history taking and physical examination skills not only to prepare for exams but to develop one's skills throughout medical school would be more difficult without the use of peers. Tolsgaard found that clinical skills training was highly beneficial when peer-learning activities were used in a clinical environment, ${ }^{3}$ therefore it would be interesting to assess if students adapted peer-learning as a studying strategy for practical examinations and if this proved effective in examination results.

In addition, the authors commented on the use of studying alone for knowledge retention; however, the study did not mention exactly how students used notes or other materials for knowledge retention. Various studies have been conducted to identify the best way to learn a substantial quantity of information, and it has been found that an efficient way for long-term retention is through testing oneself, using active recall to retrieve learned information and retesting the facts at increasing time intervals. ${ }^{4}$ Again, it would be interesting to assess if students were knowingly or unknowingly using these strategies in their studying habits by asking them if they tested themselves after learning a topic, if they used flashcards to recall information and how frequently they repeated a topic in specific time intervals.

In summary, Bin Abdulrahman et al $^{1}$ has provided us with a useful insight into the most frequently used studying strategies used by medical students in order to consolidate skills and knowledge and prepare for examinations. However, 
additional information would be useful to differentiate between certain strategies used depending on the nature of examinations. Furthermore, it would be interesting to evaluate how students studied not only in terms of materials used but also in relation to evidence-based methods such as testing oneself, using active recall and repeating at intervals.

\section{Disclosure}

The author reports no conflicts of interest for this communication.

\section{References}

1. Bin Abdulrahman KA, Khalaf AM, Bin Abbas FB, Alanazi OT. Study habits of highly effective medical students. Adv Med Educ Pract. 2021;12:627.

2. Keifenheim KE, Teufel M, Ip J, et al. Teaching history taking to medical students: a systematic review. BMC Med Educ. 2015;15:1-2. doi:10.1186/s12909-015-0443-x

3. Rønnebæ TMG. Clinical skills training in undergraduate medical education using a student-centered approach. Dan Med J. 2013;60: B4690.

4. Augustin M. How to learn effectively in medical school: test yourself, learn actively, and repeat in intervals. Yale J Biol Med. 2014;87:2.

Dove Medical Press encourages responsible, free and frank academic debate. The content of the Advances in Medical Education and Practice 'letters to the editor' section does not necessarily represent the views of Dove Medical Press, its officers, agents, employees, related entities or the Advances in Medical Education and Practice editors. While all reasonable steps have been taken to confirm the content of each letter, Dove Medical Press accepts no liability in respect of the content of any letter, nor is it responsible for the content and accuracy of any letter to the editor.

\section{Publish your work in this journal}

Advances in Medical Education and Practice is an international, peerreviewed, open access journal that aims to present and publish research on Medical Education covering medical, dental, nursing and allied health care professional education. The journal covers undergraduate education, postgraduate training and continuing medical education including emerging trends and innovative models linking education, research, and health care services. The manuscript management system is completely online and includes a very quick and fair peer-review system. Visit http://www.dovepress.com/testimonials.php to read real quotes from published authors. 